DOI:10.18276/sip.2016.45/2-19

\title{
Urszula Gierałtowska*
}

Uniwersytet Szczeciński

\section{FUNDUSZE ETF NOTOWANE NA GIEŁDZIE PAPIERÓW WARTOŚCIOWYCH W WARSZAWIE}

\begin{abstract}
Streszczenie
Celem artykułu jest próba oceny skuteczności ETF na GPW w Warszawie. Rynek ETF w Polsce jest niezwykle młody i mało zróżnicowany. Pierwszy ETF pojawił się na GPW we wrześniu 2010 roku. Obecnie notowane są trzy ETF (na WIG20, DAX oraz S\&P 500). Podstawowe zalety ETF to: wysoka płynność, prostota i przejrzystość instrumentu, niskie koszty zarządzania i dość wierna replikacja indeksu. W artykule przedstawiono również efektywność ETF na tle portfeli zbudowanych na bazie spółek wchodzących w skład wybranych indeksów giełdowych. ETF mogą stanowić atrakcyjne narzędzie długoterminowych inwestycji, zwłaszcza dla inwestorów indywidualnych.
\end{abstract}

Slowa kluczowe: fundusze ETF, fundusze inwestycyjne, fundusze zarządzane pasywnie, błąd odwzorowania

\section{Wstęp}

Jednym z młodszych instrumentów rynku kapitałowego są fundusze exchange-traded fund $(\mathrm{ETF})^{1}$. Na świecie od wielu lat jest to bardzo popularna forma inwe-

* Adres e-mail: urszula.gieraltowska@wneiz.pl.

1 Exchange-traded fund to instrument, który łączy w sobie cechy akcji i funduszy inwestycyjnych. Jest to rodzaj otwartego funduszu inwestycyjnego, którego celem jest śledzenie ruchu indeksów giełdowych, surowców czy koszyka innych aktywów, np. akcji lub obligacji, zatem są to fundusze zarządzane pasywnie. 
stowania ${ }^{2}$ przynosząca wymierne korzyści, zwłaszcza w porównaniu z inwestowaniem w zwykłe fundusze akcyjne. Pierwsze próby utworzenia funduszu typu ETF na świecie podjęto w roku 1989, jednak pierwszy ETF sensu stricte rozpoczął działalność w styczniu 1993 roku w Stanach Zjednoczonych - Standard \& Poor's jest dziś jednym z największych i najbardziej aktywnie funkcjonujących funduszy. Szacuje się, że na koniec 2014 roku na świecie funkcjonowało 3906 ETF, z czego w Stanach Zjednoczonych - 1380. Wartość aktywów oscylowała na poziomie 2 640,5 mld USD, z czego wartość rynku amerykańskiego kształtowała się na poziomie 1922,46 mld USD, rynek europejski szacuje się na 438,87 mld USD, a rynek Azji i Pacyfiku na 201,35 mld USD (Lan, Mercado, Rajenda, Gademsetty, 2015). W latach 2003-2014 nastąpił prawie 13-krotny wzrost wartości aktywów zarządzanych przez ETF przy ponad 14-krotnym wzroście ich liczby. Świadczy to przede wszystkich o rosnącym zainteresowaniu ze strony inwestorów tą formą lokowania kapitału.

Rynek ETF w Polsce jest niezwykle młody i mało zróżnicowany. Możliwość tworzenia ETF pojawiła się w Polsce wraz z wejściem w życie ustawy o funduszach inwestycyjnych (z 28 sierpnia 1997 r.), jednak pierwsze próby wprowadzenia ETF na polski rynek giełdowy pojawiły się dopiero w 2002 roku, kiedy obecne BPH TFI chciało utworzyć fundusz inwestycyjny mieszany, którego celem miało być naśladowanie zmian jednego z najpopularniejszych indeksów rynku akcji: DAX lub S\&P 500 (wybór indeksu uzależniony był od zainteresowania inwestorów). Debiut funduszu nie doszedł do skutku z uwagi na niewielkie zainteresowanie ze strony potencjalnych inwestorów instytucjonalnych. Faktyczny debiut ETF na GPW miał miejsce 22 września 2010 roku, kiedy odbyło się pierwsze notowanie Lyxor ETF WIG20. Obecnie (wrzesień 2015 r.) na GPW notowane są tytuły uczestnictwa trzech ETF - ETF WIG20³, ETF S\&P 500, ETF DAX ${ }^{4}$. Są one zgodne z wymogami dyrektywy europejskiej dotyczącej funkcjonowania funduszy otwartych (UCITS III). Emitentem wszystkich funduszy jest Lyxor Asset Management należący do grupy kapitałowej Société Generale.

\footnotetext{
s. 462 i n.).

Więcej o genezie i rozwoju funduszy ETF znaleźć można m.in. w pracy (Miziołek, 2013,

3 Fundusz oparty na WIG20 funkcjonuje pod nazwą ETFW20L, jednak w artykule wykorzystywany będzie zapis ETF WIG20 celem prostszej wizualizacji i interpretacji.

4 Jednostkę notowania stanowi jeden tytuł uczestnictwa, którego wartość początkowa odzwierciedlała ułamek instrumentu bazowego. W przypadku ETF WIG20 była to 1/10 wartości indeksu WIG20, a w przypadku dwóch pozostałych funduszy - 1/100 wartości odpowiednio w euro dla indeksu DAX i w USD dla S\&P 500.
} 


\section{Wady i zalety funduszy ETF}

Alokacja kapitału w ETF ma wiele pozytywnych i negatywnych stron. Wśród zalet inwestowania w ETF wymienić należy (Gabryelczyk, 2009, s. 238 i n.; Miziołek, 2013, s. 371 i n.):

a) niskie koszty zarządzania - pasywne zarządzanie portfelem inwestycyjnym sprawia, że koszty zarządzania są istotnie niższe (ok. 0,15-0,50\%) niż w aktywnie zarządzanych klasycznych funduszach inwestycyjnych; jest to szczególnie istotne z punktu widzenia inwestowania długoterminowego;

b) elastyczność i bieżącą wycenę - dzięki temu, że jednostki ETF notowane są w systemie notowań ciągłych, istnieje duża elastyczność w zakresie ich kupna i sprzedaży;

c) efektywność podatkową;

d) przejrzystość i prostotę - inwestując w ETF, inwestujemy na podstawie konkretnego indeksu giełdowego, branżowego czy surowcowego, znamy strukturę aktywów i posiadamy pełną kontrolę nad portfelem inwestycyjnym;

e) możliwość ekspozycji na wybrany region, sektor czy segment rynku, przez co maksymalizujemy dywersyfikację portfela (jest to widoczne szczególnie na rynkach zachodnich, gdzie oferta funduszy jest bardziej zróżnicowana);

f) możliwość wypłaty dywidendy - inwestorowi może być wypłacana przez fundusz dywidenda będąca ekwiwalentem dywidendy wypłacanej przez spółki wchodzące w skład indeksu;

g) niskie bariery wejścia;

h) silną korelację z indeksem;

i) bezpieczeństwo - funkcjonowanie ETF uregulowane jest poprzez akty prawne ${ }^{5}$, a nadzór nad rynkiem sprawuje organ nadzoru nad rynkiem kapitałowym lub finansowym.

ETF nie są jednak pozbawione wad. Wśród najistotniejszych wymienić należy:

a) małą ofertę ETF w Polsce;

b) brak możliwości selekcji spółek lub walorów wchodzących w skład indeksów;

c) koszty transakcyjne - dodatkowym kosztem jest prowizja maklerska oraz spread pomiędzy ofertami kupna i sprzedaży jednostek;

d) tracking error - nie odwzorowują indeksów w 100\%;

5 W Polsce ustawa o funduszach inwestycyjnych z 27 maja $2004 \mathrm{r}$. 
e) ryzyko walutowe - w przypadku inwestowania w instrumenty notowane na zagranicznych rynkach;

f) inwestor może zarabiać tylko na rosnącym rynku (brak short-ETF na polskim rynku);

g) ryzyko delistingu, czyli możliwości usunięcia ETF z giełdy;

h) brak możliwości uzyskania ponadprzeciętnej stopy zwrotu.

\section{Rynek ETF na GPW}

Wprowadzenie ETF na polski rynek kapitałowy rozszerzyło możliwości inwestycyjne potencjalnych inwestorów, jednak nie spotkało się to ze zbyt dużym zainteresowaniem z ich strony. Udział miesięcznych obrotów trzech dostępnych aktualnie ETF w obrotach na przykład na rynku akcji jest znikomy. W tabeli 1 zawarto podstawowe informacje dotyczące statystyk obrotu jednostkami ETF na GPW w latach 2010-2014.

Tabela 1. Podstawowe wskaźniki giełdowe dla ETF na GPW w latach 2010-2014

\begin{tabular}{|c|c|c|c|c|c|}
\hline & 2010 & 2011 & 2012 & 2013 & 2014 \\
\hline \multicolumn{6}{|c|}{ ETF - notowania ciągłe } \\
\hline $\begin{array}{l}\text { Liczba notowanych serii } \\
\text { na koniec roku }\end{array}$ & 1 & 3 & 3 & 3 & 3 \\
\hline $\begin{array}{l}\text { Wartość obrotów w całym roku } \\
\text { [tys. zł] }]^{*}\end{array}$ & 70515 & 259718 & 217126 & 169356 & 103015 \\
\hline Średnie obroty na sesję [tys. zł] & 279 & 1035 & 872 & 686 & 414 \\
\hline Liczba transakcji na sesję & 10 & 35 & 29 & 43 & 41 \\
\hline Średnia wartość transakcji [zł] & 26822 & 29798 & 29825 & 15965 & 9980 \\
\hline Wolumen obrotu na sesję & 1026 & 4178 & 4479 & 4038 & 2066 \\
\hline $\begin{array}{l}\text { Wartość aktywów netto ogółem } \\
\text { [tys. zł] }\end{array}$ & 251357 & 3418025 & 3248486 & 3642541 & 2789067 \\
\hline $\begin{array}{l}\text { Wartość aktywów netto } \\
\text { na jednostkę [zł] }\end{array}$ & 279,29 & 514,15 & 618,44 & 705,00 & 742,91 \\
\hline \multicolumn{6}{|c|}{ ETF - transakcje pakietowe } \\
\hline $\begin{array}{l}\text { Liczba zawartych transakcji } \\
\text { [pojedynczo] }\end{array}$ & 5 & 5 & 1 & - & - \\
\hline $\begin{array}{l}\text { Średnia wartość transakcji } \\
\text { [tys. zł] }\end{array}$ & 2923 & 4918 & 6045 & - & - \\
\hline $\begin{array}{l}\text { Wartość obrotów w całym roku } \\
\text { [tys. zł] }\end{array}$ & 14616 & 24590 & 6045 & - & - \\
\hline
\end{tabular}

* bez transakcji pakietowych Źródło: Rocznik Giełdowy 2015. 
Od początku 2015 roku obroty wyniosły już w sumie 209,81 mln zł, co jest kwotą wyższą o 103,7\% w porównaniu do obrotów w całym 2014 roku. Należy również zauważyć, że istotnemu wzrostowi wartości obrotów w ostatnich miesiącach towarzyszył wzrost liczby zawartych transakcji.

Rysunek 1. Wartość obrotów tytułami uczestnictwa funduszy ETF na GPW w Warszawie oraz liczba transakcji w ujęciu miesięcznym (I 2013 - VIII 2015)

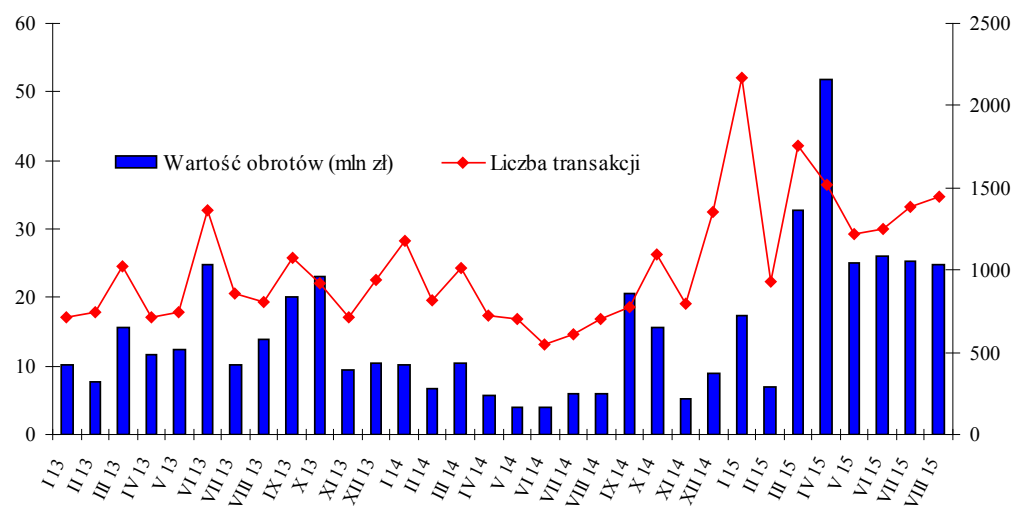

Źródło: opracowanie własne na podstawie danych GPW.

Tabela 2. Wartość obrotów tytułami uczestnictwa poszczególnych ETF na GPW oraz liczba transakcji (ujęcie sumaryczne za okres 2013 - sierpień 2015)

\begin{tabular}{|l|c|c|c|c|c|c|}
\hline \multirow{2}{*}{ Indeks } & \multicolumn{3}{|c|}{ Wartość obrotów $[\mathrm{mln}$ zł]/[\%] } & \multicolumn{3}{c|}{ Liczba transakcji [liczba]/[\%] } \\
\cline { 2 - 7 } & 2013 & 2014 & I-VIII 2015 & 2013 & 2014 & I-VIII 2015 \\
\hline \multirow{2}{*}{ ETF WIG20 } & 129,94 & 76,7 & 127,13 & 8370 & 5453 & 5059 \\
\cline { 2 - 7 } & 76,7 & 68,8 & 60,6 & 78,9 & 52,8 & 43,3 \\
\hline \multirow{2}{*}{ ETF DAX } & 15,11 & 19,99 & 59,23 & 1043 & 1907 & 3114 \\
\cline { 2 - 7 } & 8,9 & 19,4 & 28,2 & 9,8 & 18,5 & 26,7 \\
\hline \multirow{2}{*}{ ETF S\&P 500 } & 24,31 & 12,15 & 23,45 & 1195 & 2962 & 3504 \\
\cline { 2 - 7 } & 14,4 & 11,8 & 11,2 & 11,3 & 28,7 & 30,0 \\
\hline \multirow{2}{*}{ Lącznie } & 169,36 & 103,01 & 209,81 & 10608 & 10322 & 11677 \\
\hline
\end{tabular}

Źródło: opracowanie własne na podstawie danych GPW.

Od samego początku największą popularnością wśród inwestorów cieszą się ETF na indeks WIG20 (tabela 2). To typowa tendencja występująca także na innych rynkach, które posiadają w swojej ofercie tego typu instrumenty. Inwestorzy zazwy- 
czaj wybierają inwestycje w lokalne indeksy ze względu na lepszą znajomość rynku oraz silniejsze przywiązanie do niego. Jednak w ostatnich latach (a w szczególności w badanym 2015 r.) należy zwrócić uwagę na istotny spadek wartości obrotów tytułami uczestnictwa oraz liczby transakcji ETF na WIG20.

W 2015 roku wyraźnie wzrosły obroty tytułami uczestnictwa ETF DAX (ponad trzykrotnie w porównaniu do całego roku 2013) przy jednoczesnym wyraźnym wzroście liczby transakcji. W latach 2014-2015 wzrosło też zainteresowanie inwestorów ETF S\&P 500, przy czym w ujęciu wartościowym udział obrotów wykazuje tendencję spadkową.

Niezwykle istotną informacją jest wysokość stóp zwrotu uzyskiwanych z różnych instrumentów. W przypadku badanych funduszy (tabela 3) ich stopy zwrotu były wyraźnie zróżnicowane. Warte podkreślenia jest to, że w przypadku ETF DAX oraz ETF S\&P 500 były to stopy wyższe niż stopy zwrotu uzyskane $\mathrm{z}$ benchmarków. Choć jak wynika z definicji ETF, to fundusze zarządzane pasywnie, zatem nie starają się pobić indeksu, jednak często pozwalają na wyższe zyski niż bezpośrednia inwestycja w indeksy, na których bazują.

Tabela 3. Stopy zwrotu [\%] ETF i odpowiadających im indeksów w okresie od debiutu funduszu na GPW (22 września 2010/31 maja 2011) do 31 sierpnia 2015 roku

\begin{tabular}{|l|c|c|c|c|c|c|c|}
\hline Indeks & $2010^{*}$ & 2011 & 2012 & 2013 & 2014 & $2015^{* * *}$ & Od debiutu \\
\hline WIG20 & 5,90 & $-21,85$ & 20,45 & $-7,05$ & $-3,54$ & $-6,57$ & $-16,50$ \\
\hline WIG20TR & 6,60 & $-18,10$ & 29,55 & $-1,81$ & 0,51 & $-4,74$ & 6,34 \\
\hline ETF WIG20 & 9,37 & $-20,78$ & 26,89 & $-3,97$ & $-0,18$ & $-6,55$ & $-1,51$ \\
\hline DAX & & $-19,13^{* *}$ & 29,06 & 25,48 & 2,65 & 4,63 & 40,66 \\
\hline ETF DAX & & $-6,36^{* *}$ & 14,26 & 27,44 & 5,68 & 1,70 & 47,61 \\
\hline S\&P 500 & & $-6,51^{* *}$ & 11,52 & 31,28 & 13,00 & $-5,20$ & 46,61 \\
\hline ETF S\&P 500 & & $19,22^{* *}$ & 1,15 & 29,85 & 34,29 & 1,44 & 113,29 \\
\hline
\end{tabular}

* stopa zwrotu liczona w okresie 22 września - 31 grudnia 2010 roku

** stopa zwrotu liczona w okresie 31 maja - 31 grudnia 2011 roku

${ }^{* * *}$ stopa zwrotu liczona w okresie 1 stycznia - 31 sierpnia 2015 roku

Źródło: opracowanie własne na podstawie www.stooq.com.

6 WIG20 jest indeksem cenowym, co oznacza, że w przeciwieństwie do WIG20 Total Return, który jest indeksem dochodowym, nie uwzględnia dochodów inwestorów z tytułu dywidendy i prawa poboru. Dochody te w przypadku ETF jak najbardziej wpływają na wzrost wartości jego aktywów, dlatego też to właśnie WIG20 Total Return jest tym właściwszym do porównań. 


\section{Ocena stopnia naśladowania}

Jak już wcześniej podkreślano, z założenia ETF powinny wiernie naśladować zmiany indeksów. Pomimo faktu, że analizowane fundusze stosują replikację syntetyczną (z zastosowaniem swapów), to w praktyce kurs wszystkich notowanych na GPW funduszy odbiegał od przyjętych założeń (rysunek 2). Największe różnice widoczne są w przypadku funduszy odwzorowujących indeksy giełd zagranicznych. Jest to zjawisko dość powszechne na globalnym rynku kapitałowym, jednak skala rozbieżności w przypadku ETF S\&P 500 i indeksu S\&P 500 jest dość wysoka.

Obserwując sytuację ETF WIG20, można zauważyć, że pod koniec 2011 roku nastąpił wyraźny rozjazd cenowy pomiędzy kursem ETF i indeksu WIG20. Lyxor zaprzestał wówczas wypłaty dywidendy (zrobił to jedynie dwukrotnie - w marcu i grudniu 2011 r.), która automatycznie była reinwestowana. Od początku 2012 roku ETF naśladuje indeks WIG20 Total Return.

Rysunek 2. Kursy ETF notowanych na GPW oraz odpowiadających im benchmarków (od momentu debiutu funduszu do 31 sierpnia 2015 roku)

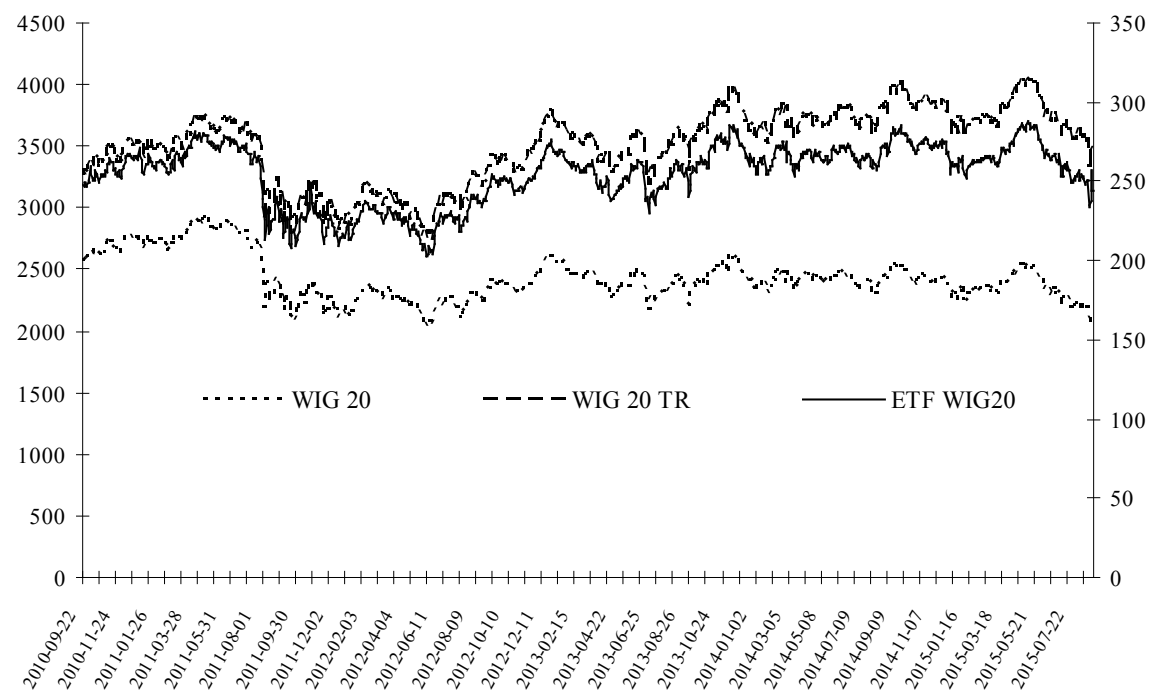



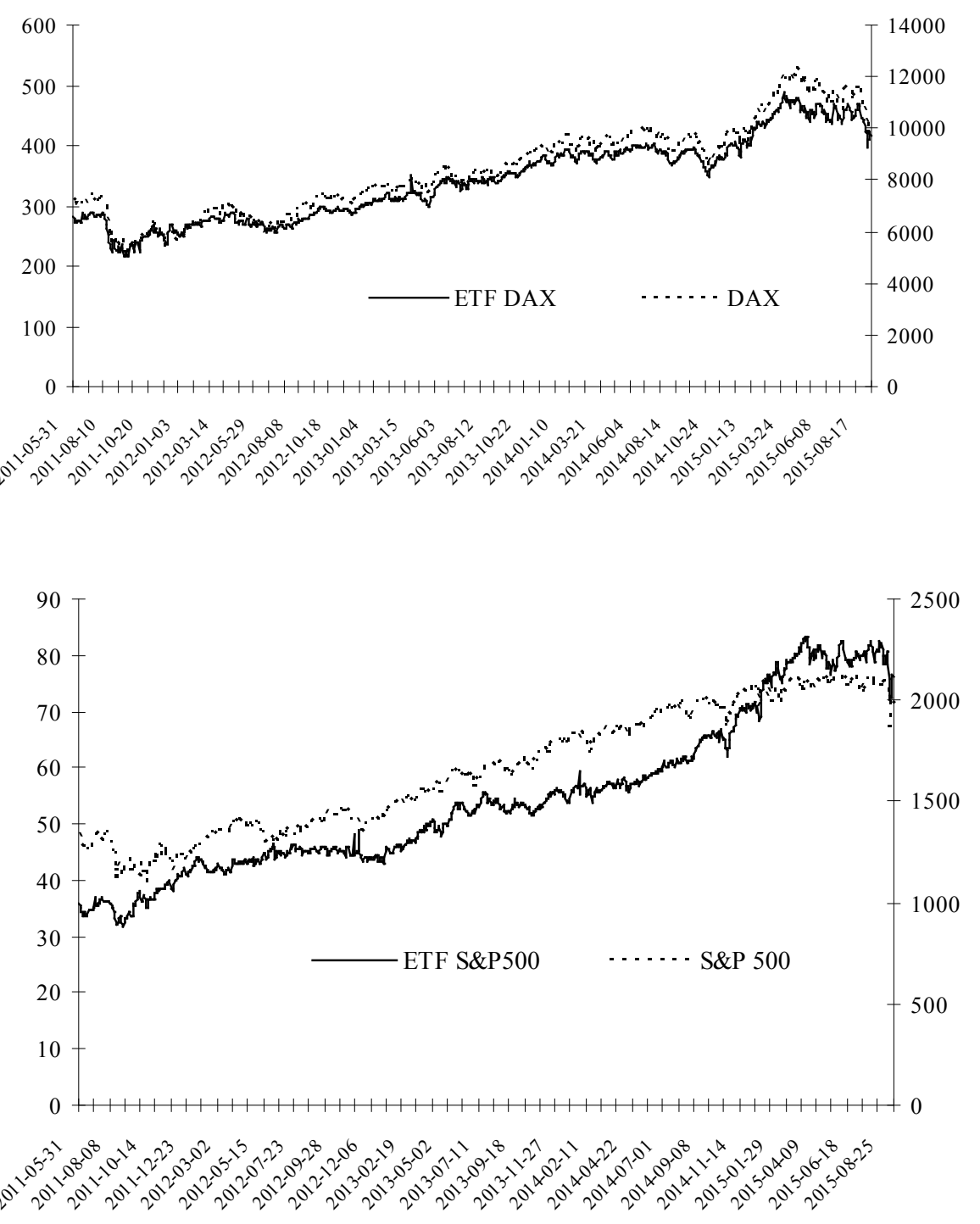

Źródło: opracowanie własne na podstawie www.stooq.com.

Różnica pomiędzy stopą zwrotu funduszu a stopą zwrotu replikowanego indeksu określana jest jako błąd naśladowania (tracking error). Parametr ten jest jednym z mierników oceny efektywności funduszy zarządzanych pasywnie . W literaturze występuje szereg miar, które opisują błąd naśladowania. W niniejszym opracowaniu wykorzystano wybrane mierniki $T E_{i}$ opisane wzorami (1)-(4). 


$$
\begin{gathered}
T E_{1}=\sqrt{\frac{1}{N-1} \sum\left(r_{F}-r_{B}\right)^{2}} \text { (Vardharaj, Fabozzi, Jones, 2004, s. 37-47) } \\
T E_{2}=\frac{1}{N} \sum\left|r_{F}-r_{B}\right| \\
T E_{3}=\sqrt{\frac{1}{N-1} \sum\left(R D_{t}-\overline{R D}\right)^{2}} \quad R D_{t}=\left|r_{F}-r_{B}\right| \\
T E_{4}=\sigma_{F} \sqrt{\left(1-\rho_{F B}\right)^{2}}
\end{gathered}
$$

gdzie:

$r_{F}-$ dzienna/tygodniowa logarytmiczna stopa zwrotu funduszu,

$r_{B}$ - dzienna//tygodniowa logarytmiczna stopa zwrotu wzorca odwzorowania, $N$ - liczba okresów zwrotu,

$\rho_{F B}-$ współczynnik korelacji pomiędzy stopami zwrotu funduszu i benchmarku, $\sigma_{F}$ - odchylenie standardowe stóp zwrotu ETF.

Im niższa jest wartość błędu naśladowania, tym lepsze jest odzwierciedlenie wyników benchmarku, a zatem ryzyko jest niższe. Z kolei im wartość wskaźnika tracking error jest wyższa, tym fundusz gorzej odwzorowuje rezultaty osiągane przez benchmark, a więc ryzyko jest wyższe. Dodatkowo w sytuacji, w której zmienność stóp zwrotu wzrasta, rośnie również wartość wskaźnika błędu odwzorowania. W literaturze postuluje się, aby w przypadku funduszy zarządzanych pasywnie błąd odwzorowania nie przekroczył 1,0-1,5\%. Jednak w przypadku zajścia nieoczekiwanych zdarzeń na rynkach finansowych istnieje ryzyko wzrostu tego odchylenia.

Analizując wartości błędów odwzorowania zamieszczonych w tabeli 4, należy zwrócić uwagę, że najlepiej odwzorowuje indeks fundusz ETF WIG20. Dla wskaźników $T E_{1}-T E_{3}$ oscylują one na poziomie $0,3-1,0 \%$, a ich niskie wartości są zgodne z pasywnym charakterem funduszu. Błąd odwzorowania w przypadku pozostałych dwóch funduszy jest dużo wyższy. Szczególnie wysokie wartości przyjmują wskaźniki liczone dla 5-letniego okresu funkcjonowania funduszy (od debiutu), co wynika przede wszystkim z niskiego zainteresowania inwestorów funduszami w pierwszych latach ich notowań. W kolejnych okresach wartość błędu spadała, ale i tak była wyższa niż w przypadku ETF WIG20.

7 Parametr $T E_{4}$ oznacza zmienność błędu odwzorowania (Miziołek, 2013, s. 509). 
Należy także zwrócić uwagę na zróżnicowane wartości wskaźnika $T E_{4}$, które świadczą o zmienności błędu odwzorowania. Najniższe wartości wskaźnika $T E_{4}$ otrzymano dla instrumentów, dla których zróżnicowanie stóp zwrotu w analizowanych okresach kształtuje się na zbliżonym poziomie do zróżnicowania benchmarku. Największe wartości błędu naśladowania zanotowano w okresach o wyższym odchyleniu standardowym dziennych stóp zwrotu. Należy również zauważyć, że odchylenia od notowań indeksu bazowego działają na korzyść inwestorów, pozwalają bowiem osiągać wyższe stopy zwrotu.

Tabela 4. Wartości wybranych błędów odwzorowania [\%] ETF liczone na podstawie logarytmicznej dziennej i tygodniowej stopę zwrotu

\begin{tabular}{|c|c|c|c|c|c|c|c|c|}
\hline & $T E_{1}$ & $T E_{2}$ & $T E_{3}$ & $T E_{4}$ & $T E_{1}$ & $T E_{2}$ & $T E_{3}$ & $T E_{4}$ \\
\hline & \multicolumn{4}{|c|}{ logarytmiczne dzienne stopy zwrotu } & \multicolumn{4}{|c|}{ logarytmiczne tygodniowe stopy zwrotu } \\
\hline & \multicolumn{8}{|c|}{ ETF WIG20 } \\
\hline 2013 & 0,547 & 0,427 & 0,342 & 0,134 & 0,553 & 0,431 & 0,351 & 0,061 \\
\hline 2014 & 0,557 & 0,433 & 0,351 & 0,164 & 0,582 & 0,455 & 0,364 & 0,085 \\
\hline $2015^{*}$ & 0,995 & 0,535 & 0,839 & 0,424 & 1,017 & 0,559 & 0,850 & 0,250 \\
\hline \multirow[t]{2}{*}{ Od debiutu } & 0,709 & 0,465 & 0,535 & 0,214 & 0,738 & 0,494 & 0,548 & 0,109 \\
\hline & \multicolumn{8}{|c|}{ ETF DAX } \\
\hline 2013 & 0,987 & 0,592 & 0,790 & 0,491 & 1,232 & 0,815 & 0,924 & 0,379 \\
\hline 2014 & 0,698 & 0,501 & 0,486 & 0,225 & 0,846 & 0,644 & 0,550 & 0,142 \\
\hline $2015^{*}$ & 0,735 & 0,575 & 0,458 & 0,176 & 1,063 & 0,843 & 0,650 & 0,166 \\
\hline \multirow[t]{2}{*}{ Od debiutu } & 1,127 & 0,752 & 0,840 & 0,470 & 1,472 & 1,045 & 1,037 & 0,350 \\
\hline & \multicolumn{8}{|c|}{ ETF S\&P 500} \\
\hline 2013 & 0,948 & 0,749 & 0,582 & 0,615 & 1,746 & 1,379 & 1,071 & 0,980 \\
\hline 2014 & 1,104 & 0,752 & 0,812 & 0,777 & 1,346 & 1,047 & 0,906 & 0,512 \\
\hline $2015^{*}$ & 1,273 & 0,973 & 0,822 & 0,792 & 2,049 & 1,665 & 1,207 & 0,997 \\
\hline Od debiutu & 1,436 & 0,978 & 1,052 & 1,019 & 2,192 & 1,654 & 1,449 & 1,135 \\
\hline
\end{tabular}

* wskaźniki liczone w okresie 1 stycznia - 30 sierpnia 2015 roku

Źródło: opracowanie własne.

Można też zauważyć, że wykorzystanie dziennych stóp zwrotu daje niższe błędy odwzorowania niż w przypadku wykorzystania tygodniowych rolowanych stóp zwrotu. Jednak z drugiej strony im wyższa częstotliwość stopy zwrotu, tym większa wrażliwość błędu odwzorowania (dla danych tygodniowych widoczne są wyższe wartości wskaźników $T E_{1}-T E_{3}$ przy jednoczesnym spadku wartości wskaźnika $T E_{4}$ ). 


\section{ETF na tle wybranych portfeli akcji}

W zależności od przyjętej postawy, posiadanej wiedzy, możliwości finansowych oraz horyzontu czasowego inwestycji inwestor ma do dyspozycji instrumenty o zróżnicowanym poziomie: płynności, ryzyka, osiąganej stopy zwrotu i dostępności. Jak już wcześniej pokreślono, inwestorzy coraz częściej poszukują prostych i przejrzystych instrumentów odzwierciedlających zachowania określonych indeksów rynkowych bez konieczności ponoszenia wysokich kosztów transakcyjnych, które jednocześnie charakteryzują się dużą płynnością oraz brakiem barier wejścia/wyjścia.

W artykule podjęto próbę porównania efektywności ETF notowanych na GPW na tle wybranych portfeli budowanych na bazie akcji wchodzących w skład wybranych indeksów giełdowych. Każdorazowo wybrano 20 spółek, których udział w indeksie był największy (według stanu na 31 grudnia 2014 r.):

- portfel $P 1$ - spółki wchodzące w skład indeksu WIG20,

- portfel $P 2$ - spółki wchodzące w skład indeksu WIG30,

- portfel P3 - spółki wchodzące w skład indeksu WIG40,

- portfel P4 - spółki wchodzące w skład indeksu WIG div,

- portfel $P 5$ - spółki wchodzące w skład RESPECT index,

- portfel P6 - spółki o największych obrotach w 2014 roku.

Zagadnienie optymalizacyjne dotyczące ustalenia wielkości udziałów poszczególnych akcji spółek w portfelu, które pozwoliło na znalezienie minimalnej wartości ryzyka portfela przy zadanej wartości spodziewanej stopy zwrotu, rozwiązano, wykorzystując model decyzyjny opracowany przez H. Markowitza.

Każdy inwestor, przystępując do sformułowania planu inwestycyjnego, musi określić horyzont inwestycyjny. Zasadniczo zależy on od indywidualnych preferencji inwestora, jak również od sytuacji rynkowej. Inwestycje w akcje powinny mieć charakter inwestycji średnio- lub długoterminowych, pozwoli to bowiem inwestorowi na zdroworozsądkowe podejście do zarządzania portfelem. Przyjęto założenie, że portfele będą budowane na bazie stóp zwrotu osiągniętych w 2014 roku. Parametry portfeli minimalnego ryzyka przedstawiono w tabeli 5. 
Tabela 5. Parametry wybranych portfeli inwestycyjnych

\begin{tabular}{|l|c|c|c|c|c|c|}
\hline \multirow{2}{*}{\begin{tabular}{c}
\multirow{2}{*}{$\begin{array}{c}\text { Parametry } \\
\text { portfela }\end{array}$} \\
\cline { 2 - 7 }
\end{tabular}} & $P 1$ & P2 & P3 & P4 & P5 & P6 \\
\hline Stopa zwrotu & $-0,020 \%$ & $0,045 \%$ & $0,045 \%$ & $0,046 \%$ & $0,033 \%$ & $0,021 \%$ \\
\hline Ryzyko & $0,807 \%$ & $0,797 \%$ & $0,734 \%$ & $0,699 \%$ & $0,751 \%$ & $0,918 \%$ \\
\hline Liczba walorów & 12 & 12 & 11 & 14 & 16 & 16 \\
\hline
\end{tabular}

Źródło: obliczenia własne.

W celu przeprowadzenia porównań założono także, że inwestor dysponuje kwotą 100 tys. zł. W celu uproszczenia obliczeń zarówno przy zakupie, jak i sprzedaży pominięto wszelkiego rodzaju opłaty manipulacyjne (m.in. prowizję biura maklerskiego). Założono jednocześnie, że inwestor nie poddaje stałej kontroli optymalności portfela i nie dokonuje zmian w jego składzie w czasie trwania inwestycji. Zakupu akcji dokonano 31 grudnia 2014 roku, natomiast ich sprzedaż nastąpiła 10 września 2015 roku. Uzyskane stopy zwrotu przedstawiono w tabeli 6.

Analizując wyniki zaprezentowane w tabeli 6, można zwrócić uwagę, że jedynie dla portfela P4 (zbudowanego na bazie spółek wchodzących w skład indeksu WIG div) uzyskano dodatnią stopę zwrotu. Warte podkreślenia jest to, że wszystkie ETF notowane na GPW uzyskały lepsze wyniki niż portfele budowane na bazie wybranych akcji, przy czym należy zauważyć, że w obliczeniach nie uwzględniono kosztów transakcyjnych, bowiem wyniki analizowanych portfeli byłyby jeszcze gorsze.

Tabela 6. Poziom faktycznych stóp zwrotu [\%] według stanu na 10 września 2015 roku

\begin{tabular}{|c|c|c|c|c|c|}
\hline \multicolumn{6}{|c|}{ Portfele akcji } \\
\hline $\mathrm{P} 1$ & $\mathrm{P} 2$ & P3 & $\mathrm{P} 4$ & P5 & P6 \\
\hline$-7,164$ & $-9,956$ & $-19,327$ & 0,449 & $-12,992$ & $-7,867$ \\
\hline \multicolumn{6}{|c|}{ Fundusze ETF } \\
\hline \multicolumn{2}{|c|}{ ETF WIG20 } & \multicolumn{2}{|c|}{ ETF DAX } & \multicolumn{2}{|c|}{ ETF S\&P 500} \\
\hline \multicolumn{2}{|c|}{$-5,170$} & \multicolumn{2}{|c|}{1,973} & \multicolumn{2}{|c|}{$-0,493$} \\
\hline \multicolumn{6}{|c|}{ Indeksy giełdowe } \\
\hline \multicolumn{2}{|c|}{ WIG20 } & \multicolumn{2}{|l|}{ WIG20 TR } & $\mathrm{DAX}$ & S\&P 500 \\
\hline \multicolumn{2}{|c|}{$-5,656$} & $-3,780$ & \multicolumn{2}{|c|}{4,129} & $-6,156$ \\
\hline
\end{tabular}

Źródło: obliczenia własne. 
Uzyskane wyniki pozwalają przypuszczać, że pomimo tego, iż ETF nie cieszą się dużym zainteresowaniem wśród inwestorów, to w długim horyzoncie czasu inwestowanie $\mathrm{w}$ nie może być trafnym pomysłem inwestycyjnym na dodatkowe zabezpieczenie przyszłości. Dotyczyć to może przede wszystkim przyszłych emerytów, zatem kryzys systemu emerytalnego może być bodźcem do rozwoju rynku ETF w Polsce.

\section{Podsumowanie}

Rynek ETF w Polsce ciągle pozostaje w początkowej fazie rozwoju. Skala obrotów tymi instrumentami jest niewielka w porównaniu do innych funduszy rynku kapitałowego czy instrumentów notowanych na GPW. Podstawową przyczyną tego stanu rzeczy jest bardzo słaba znajomość wśród inwestorów indywidualnych funkcjonowania i zalet ETF. Dodatkowym ograniczeniem rozwoju jest słaba koniunktura polskiej gospodarki, niezbyt optymistyczna sytuacja na GPW i osiągane przez nią wyniki oraz niewielka aktywność inwestorów indywidualnych. Można przypuszczać, że wraz z poprawą sytuacji gospodarczej oferta funduszy będzie się stopniowo powiększać.

Obserwując rosnącą popularność ETF na świecie, należy wnioskować, iż są one nieodzownym elementem oferty każdego rozwiniętego rynku kapitałowego. Wprowadzanie ETF na GPW stanowi atrakcyjną alternatywą dla inwestorów szukających pasywnych sposobów inwestowania, zwłaszcza że niewątpliwą zaletą ETF są niskie opłaty za zarządzanie, co w połączeniu z pasywnym zarządzaniem pozwala na osiągnięcie wyższej stopy zwrotu zarówno w porównaniu do funduszy indeksowych, jak i funduszy zarządzanych aktywnie. Należy mieć również nadzieję, że na polskim rynku kapitałowym pojawią się kolejne ETF, które dadzą większe możliwości inwestycji i sprawią, że rynek ten będzie jeszcze bardziej atrakcyjny pod kątem inwestycyjnym na tle innych rynków europejskich.

\section{Literatura}

etf.com.pl (10.09.2015).

Gabryelczyk, K. (red.). (2009). Private Asset \& Wealth Management. Nowe instrumenty i ustugi finansowe. Warszawa: C.H. Beck.

Lan, S., Mercado, S., Rajenda, A., Gademsetty, A. (2015). ETF Annual Review \& Outlook. Deutsche Bank Securities Inc. Pobrane z: www.altii.de (10.09.2015). 
Miziołek, T., (2013). Pasywne zarzadzanie portfelem inwestycyjnym - indeksowe fundusze inwestycyjne i fundusze ETF. Ocena efektywności zarządzania na przykładzie akcyjnych funduszy ETF rynków wschodzacych. Łódź: Wyd. UŁ.

Rocznik Giełdowy (2015). Pobrane z: www.gpw.pl (10.09.2015).

Vardharaj, R., Fabozzi, F.J., Jones, F.J., (2004), Determinants of Tracking Error for Equity Portfolios. Journal of Investing, 13, 2, 37-47.

www.gpw.pl (10.09.2015).

www.stooq.com (10.09.2015).

\title{
ETF ON THE WARSAW STOCK EXCHANGE
}

\begin{abstract}
The purpose of this article is to characterize ETFs on the Warsaw Stock Exchange and assessment of their efficiency. ETFs market in Poland is at very early stage of their development. ETF is a new financial instrument, which was introduced in September 2010. Currently there are three ETFs - ETF WIG20, ETF DAX and ETF S\&P500. The basic advantages of ETF are: high liquidity, simplicity and clarity of the instrument, low cost and small deviations from the benchmark. In long-term horizon the effectiveness of ETF were compared with stock market portfolios. They can be an attractive long-term investment, especially for individual investors.
\end{abstract}

Translated by Urszula Gieraltowska

Keywords: exchange-traded funds (ETF), investment funds, passive management funds, tracking error

JEL Codes: G10. G11, G23 